\author{
Fernando Frutos-Vivar \\ Niall D. Ferguson \\ Andrés Esteban
}

\title{
Mechanical ventilation: quo vadis?
}

Received: 19 January 2009

Accepted: 19 February 2009

Published online: 14 March 2009

(C) Springer-Verlag 2009

This editorial refers to the article available

at: doi:10.1007/s00134-009-1449-9.

F. Frutos-Vivar · A. Esteban (®)

Intensive Care Unit, Hospital Universitario de Getafe,

Carretera de Toledo Km 12,500, 28905 Getafe, Madrid, Spain

e-mail: aesteban@ucigetafe.com

Tel.: +34-916834982

Fax: +34-916832095

F. Frutos-Vivar · A. Esteban

CIBER Enfermedades Respiratorias, Barcelona, Spain

\section{N. D. Ferguson}

Interdepartmental Division of Critical Care Medicine, University of Toronto, Toronto, Canada

\section{N. D. Ferguson}

Division of Respirology, Department of Medicine, University Health Network, University of Toronto, Toronto, Canada

The widespread use of positive-pressure ventilation for ongoing life support began after its value was demonstrated with a dramatic reduction in mortality during the 1952 polio epidemic in Copenhagen [1]. From this year until now, mechanical ventilation has become the most common procedure in the management of critically ill patients, and indeed, it was the main reason for the establishment of intensive care units. Over the last several decades, the utilization of mechanical ventilation has changed significantly and, therefore, the outcome of patients who require respiratory support has improved.

In this issue of Intensive Care Medicine, Metniz et al. [2] describe the utilization of mechanical ventilation in 299 units from 35 countries that participated in the SAPS 3 study [3]. In general, their results are similar to those published in previous epidemiological studies of mechanical ventilation [4-7]. An important first point is that more than half of the patients received mechanical ventilation immediately on admission to the intensive care unit. This fact confirms that mechanical ventilation is the most important procedure or technique during the daily clinical practice in the intensive care units. However, it is surprising to note the low rate of utilization of non-invasive ventilation $(4.2 \%$ at admission and $7.3 \%$ during the first 3 days) even in patients with chronic pulmonary obstructive disease (17\% of COPD patients received non-invasive ventilation). These data are in contrast with results reported in previous studies. Esteban et al. [7] showed a significant increase in the utilization of non-invasive ventilation in a period of 6 years: from $4 \%$ in 1998 to $11 \%$ in 2004; this increment was especially large in the subset of patients with COPD (from 17 to $44 \%$ ). Similarly, a survey of 70 French intensive care units showed that first-line non-invasive ventilation was significantly more common than 5 years earlier ( 23 vs. 16\%) [8]. Why are these results different between studies? First, it is likely that regional and geographic differences may have played a role. In the current study [2], the authors showed significant variation in NIV use across regions from 1.3\% (Eastern Europe) to $14 \%$ (Northern Europe). In the study by Esteban et al. [7], there were also regional differences, with NIV rates in 2004 varying from $15 \%$ in Europe to $7 \%$ in Latin-America and $5 \%$ in USA-Canada (data not previously reported). Second, seasonal differences may have influenced the casemix included in each study. Seasonal variations in the 
incidence of exacerbations of COPD have been reported $[9,10]$, and as this is the disease with the strongest evidence of benefit from non-invasive ventilation [11], it makes sense the seasonal differences may also be seen in NIV use. The studies by Esteban et al. [7] and Demoule et al. [8] were carried out in March but they included different proportions of COPD patients (7 vs. 17\%), whereas this study by Metnitz et al. [2] was performed in October, November and December, and included $7 \%$ of patients with exacerbations of COPD. Last, this finding of limited NIV use may be a result of increased successful use of non-invasive ventilation outside the ICU (e.g., in the emergency room, recovery room, hospital ward). This in turn could have created a form of selection bias, whereby only patients with a poor clinical evolution were admitted to the ICU for ongoing ventilatory support.

Despite the introduction of several new ventilator modes, assist-control volume-cycled ventilation continues to be the most commonly used mode. However, the authors also reported regional differences in the utilization of modes of ventilation; notable findings include that in the units from Australasia synchronized intermittent mandatory ventilation (SIMV) with pressure support (PSV) was most common, while in units from Northern Europe, the prevalent mode was pressurecontrolled ventilation (PCV). This latter point is consistent with a previous point, prevalence study performed in the Nordic countries, which found that the majority of patients $(86 \%)$ were ventilated with pressure-regulated modes [12]. The observed diversity can be explained because at the present time there is no strong evidence suggesting that one mode of ventilation should be chosen over another [13] and individual physicians' preferences will go toward the utilization of modes with which they are most familiar.

For many years, physicians have chosen ventilator tidal volumes between 10 and $15 \mathrm{ml} / \mathrm{kg}$. This practice in the past was justified by the fact that early experience with mechanical ventilation came from anesthesiology, where the aim of mechanical ventilation was to avoid atelectasis and maintain good oxygenation during a surgical intervention. However, we now recognize the importance of ventilator-induced lung injury [14], with both animal studies and early non-controlled human trials suggesting that certain ventilator settings (high tidal volumes and low levels of positive end-expiratory pressure) could affect the extent of lung injury and even influence outcome. A number of randomized trials have evaluated the influence of the ventilatory on the outcome of the mechanically ventilated patient with acute lung injury (ALI) [15]. Summarizing these studies shows a significant effect on mortality at day 28 with lung-protective ventilation using smaller tidal volumes (relative risk $0.74 ; 95 \%$ confidence interval: 0.61-0.88) [15]. However, debate continues, regarding to what extent it is the low tidal volume strategies being protective, or the high volume strategies being harmful; while most clinicians and experts agree that cyclic overdistention of alveoli should be avoided, the optimal target tidal volume remains to be determined. For this reason, the use of tidal volume limitation is in evolution [7] but is not universally practiced. In this study by Metnitz et al. [2] a third of patients with ARDS criteria were ventilated with a tidal volume higher than $8 \mathrm{ml} / \mathrm{kg}$ of actual body weight (approximately equivalent to $10 \mathrm{ml} / \mathrm{kg}$ of predicted body weight); data on plateau pressure were unavailable. These data suggest to us that while many clinicians are clearly focused on protecting the lung in ALI, there remains room for improvement in our delivery of mechanical ventilation to ALI patients.

Probably, no aspect of mechanical ventilation has been the subject of such an extensive literature as the use of positive end-expiratory pressure (PEEP). From the initial favorable experience of Petty and Ashbaugh [16], extensive research has been undertaken to understand the mechanisms of its beneficial actions and to determine its optimal level [17]. Although the application of a prophylactic PEEP can have a beneficial effect in patients without hypoxemic respiratory failure [18], most recent studies have focused on the effect on PEEP on mortality of patients with ALI or ARDS [19, 20]. The use of higher versus conventional levels of PEEP does not appear to have a large effect on in all-comers with ALI. However, in those with the most severe forms of disease and the worst hypoxemia, there is a suggestion that higher levels of PEEP may be beneficial in reducing the need for rescue therapy and perhaps even in reducing mortality [21, 22]. In addition, observational data suggest that the use of very low levels of PEEP may be suboptimal in ARDS patients [23]; in this regard, the fact that $16 \%$ of patients with ARDS in the current study were ventilated with a PEEP lower than $5 \mathrm{~cm}$ of water may be concerning.

Where mechanical ventilation should be going in the future? One role for the mechanical ventilator is to "buy time", allowing the patient to recover from the disease causing respiratory failure. During this period, the ideal ventilation would be that one that it further does not damage the respiratory muscle or lung parenchyma. For this objective, probably each patient needs an individual setting. While lower tidal volumes around $6-8 \mathrm{ml} / \mathrm{kg}$ PBW may be a reasonable starting point in many patients, we should recognize that this may not be ideal for every patient - some individual tailoring may be necessary [24, 25]. Patient-ventilator dyssynchrony has also been related to outcome and may be an increasing focus in the future [26]. Two newly available modes, proportional assist ventilation (PAV) and neurally adjusted ventilatory assist (NAVA) certainly appear to optimize synchrony-we await further studies to establish their effects on outcomes of importance to patients [27]. Last, what is the optimal PEEP? Nobody knows for certain, but one way to help determine it could be the use of esophageal pressures to 
estimate the transpulmonary pressure - a practice we anticipate increasing in the coming years [28].
Acknowledgments Dr. Ferguson is supported by a Canadian Institutes of Health Research New Investigator Award (Ottawa, Canada).

\section{References}

1. Colice GL (2006) Historical perspective on the development of mechanical ventilation. In: Tobin MJ (ed) Principles and practice of mechanical ventilation, Second edn. McGraw-Hill, New York, pp 1-36

2. Metnitz Ph, Metnitz B, Moreno R, Bauer P, Del Sorbo L, Hoermann Ch, Afonso de Carvalho S, Ranieri V (2009) Epidemiology of mechanical ventilation: analysis of the SAPS 3 Database. Intensive Care Med. doi: 10.1007/s00134-009-1449-9

3. Metnitz PG, Moreno RP, Almeida E, Jordan B, Bauer P, Campos RA, Iapichino G, Edbrooke D, Capuzzo M, Le Gall JR (2005) SAPS 3-from evaluation of the patient to evaluation of the intensive care unit. Part 1: objectives, methods and cohort description. Intensive Care Med 31:1336-1344

4. Esteban A, Alía I, Ibañez J, Benito S, Tobin MJ (1994) Modes of mechanical ventilation and weaning. A national survey of Spanish hospitals. The Spanish Lung Failure Collaborative Group. Chest 106:1188-1193

5. Esteban A, Anzueto A, Alía I, Gordo F, Apezteguía C, Pálizas F, Cide D, Goldwaser R, Soto L, Bugedo G, Rodrigo C, Pimentel J, Raimondi G, Tobin MJ (2000) How is mechanical ventilation employed in the intensive care unit? An international utilization review. Am J Respir Crit Care Med 161:1450-1458

6. Esteban A, Anzueto A, Frutos F, Alía I, Brochard L, Stewart TE, Benito S, Epstein SK, Apezteguía C, Nightingale P, Arroliga AC, Tobin MJ (2002) Characteristics and outcomes in adult patients receiving mechanical ventilation: a 28-day international study. JAMA 287:345-355

7. Esteban A, Ferguson ND, Meade MO, Frutos-Vivar F, Apezteguia C, Brochard L, Raymondos K, Nin N, Hurtado J, Tomicic V, González M, Elizalde J, Nightingale P, Abroug F, Pelosi P, Arabi Y, Moreno R, Jibaja M, D'Empaire G, Sandi F, Matamis D, Montañez AM, Anzueto A (2008) Evolution of mechanical ventilation in response to clinical research. Am J Respir Crit Care Med 177:170-177
8. Demoule A, Girou E, Richard JC, Taille S, Brochard L (2006) Increased use of noninvasive ventilation in French intensive care units. Intensive Care Med 32:1747-1755

9. Vilkman S, Keistinen T, Tuuponen T, Kivelä SL (1996) Seasonal variation in hospital admissions for chronic obstructive pulmonary disease in Finland. Arctic Med Res 55:182-186

10. de la Iglesia Martínez F, Pellicer Vázquez C, Ramos Polledo V, Nicolás Miguel R, Pita Fernández S, Diz-Lois Martínez F (2000) Enfermedad pulmonar obstructiva crónica y las estaciones del año. Arch Bronconeumol 36:84-89

11. Ram FS, Picot J, Lightowler J, Wedzicha JA (2004) Non-invasive positive pressure ventilation for treatment of respiratory failure due to exacerbations of chronic obstructive pulmonary disease. Cochrane Database Syst Rev 3:CD004104

12. Kárason S, Antonsen K, Aneman A, SSAI ICU-II GROUP (2002) Ventilator treatment in the Nordic countries. A multicenter survey. Acta Anaesthesiol Scand 46:1053-1061

13. Frutos-Vivar F, Ferguson ND, Esteban A (2004) Ventilator modes: which do we use and how should we use them. In: Esteban A, Anzueto A, Cook DJ (eds) Evidence-based management of patients with respiratory failure. Springer, Berlin, pp 15-20

14. Dreyfuss D, Saumon G (1998) Ventilator-induced lung injury. Lessons from experimental studies. Am J Respir Crit Care Med 157:294-323

15. Petrucci N, Iacovelli W (2007) Lung protective ventilation strategy for the acute respiratory distress syndrome. Cochrane Database Syst Rev 3:CD003844

16. Petty TL, Ashbaugh DG (1971) The adult respiratory distress syndrome: clinical features, factors influencing prognosis and principles of management. Chest 60:273-279

17. Navalesi P, Maggiore SM (2006) Positive-end expiratory pressure. In: Tobin MJ (ed) Principles and practice of mechanical ventilation, 2nd edn. McGraw-Hill, New York, pp 273-326
18. Manzano F, Fernández-Mondéjar E, Colmenero M, Poyatos ME, Rivera R, Machado J, Catalán I, Artigas A (2008) Positive-end expiratory pressure reduces incidence of ventilatorassociated pneumonia in nonhypoxemic patients. Crit Care Med 36:2225-2231

19. Gordo-Vidal F, Gómez-Tello V, Palencia-Herrejón E, Latour-Pérez J, Sánchez-Artola B, Díaz-Alersi R (2007) PEEP alta frente a PEEP convencional en el síndrome de distrés respiratorio agudo Revisión sistemática y metaanálisis. Med Intensiva 31:491501

20. Gordo-Vidal F, Gómez-Tello V, Palencia-Herrejón E, Latour-Pérez J (2008) Impacto de dos nuevos estudios en el resultado de un metaanálisis sobre la aplicación de presión positiva al final de la espiración alta a pacientes con síndrome de distrés respiratorio agudo. Med Intensiva 32:316-317

21. Meade MO, Cook DJ, Guyatt GH, Slutsky AS, Arabi YM, Cooper DJ, Davies AR, Hand LE, Zhou Q, Thabane L, Austin P, Lapinsky S, Baxter A, Russell J, Skrobik Y, Ronco JJ, Stewart TE, Lung Open Ventilation Study Investigators (2008) Ventilation strategy using low tidal volumes, recruitment maneuvers, and high positive end-expiratory pressure for acute lung injury and acute respiratory distress syndrome: a randomized controlled trial. JAMA 299:637-645

22. Mercat A, Richard JC, Vielle B, Jaber S, Osman D, Diehl JL, Lefrant JY, Prat G, Richecoeur J, Nieszkowska A, Gervais C, Baudot J, Bouadma L, Brochard L, Expiratory Pressure (Express) Study Group (2008) Positive end-expiratory pressure setting in adults with acute lung injury and acute respiratory distress syndrome: a randomized controlled trial. JAMA 299:646-655

23. Ferguson ND, Frutos-Vivar F, Esteban A, Anzueto A, Alía I, Brower RG, Stewart TE, Apezteguía C, González M, Soto L, Abroug F, Brochard L (2005) Airway pressures, tidal volumes and mortality in patients with acute respiratory distress syndrome. Crit Care Med 33:21-30 
24. Deans KJ, Minneci PC, Cui X, Banks SM, Natanson C, Eichacker PQ (2005) Mechanical ventilation in ARDS: one size does not fit all. Crit Care Med 33:1141-1143

25. Terragni PP, Rosboch G, Tealdi A, Corno E, Menaldo E, Davini O,

Gandini G, Herrmann P, Mascia L, Quintel M, Slutsky AS, Gattinoni L, Ranieri VM (2007) Tidal hyperinflation during low tidal volume ventilation in acute respiratory distress syndrome. Am J Respir Crit Care Med 175:160-166
26. Thille AW, Rodriguez P, Cabello B, Lellouche F, Brochard L (2006) Patient-ventilator asynchrony during assisted mechanical ventilation. Intensive Care Med 32:1515-1522

27. Navalesi P, Costa R (2003) New modes of mechanical ventilation: proportional assist ventilation, neurally adjusted ventilatory assist, and fractal ventilation. Curr Opin Crit Care 9:5158
28. Talmor D, Sarge T, Malhotra A, O'Donnell CR, Ritz R, Lisbon A, Novack V, Loring SH (2008) Mechanical ventilation guided by esophageal pressure in acute lung injury. N Engl J Med 359:2095-2104 